\title{
HUMAN RIGHTS CHILDREN AND WOMEN PROTECTION IN THE VERSES OF AL-AHKAM
}

\author{
Fauzi \\ Universitas Islam Negeri Ar-Raniry Aceh, Indonesia \\ fauzisaleh09@gmail.com \\ Article history:
}

Submitted: 22-11-2018 | Revised: 16-01-2019 | Revised: 18-04-2019| Accepted: 01-07-2019

\begin{abstract}
This article intends to explain the position of human rights in relation to the protection of children and women in the Qur'ān. Based on the fact that the rights to children and women are exploited across history, the author intend to examine normative legal values extracted from the Holy Qur'ān as a way of life in order to encourage each individual to respect their rights. This research was conducted with a study of documentation as the technical analysis of data collection and analyzed by semi-thematic of ayat al-Ahkam. From a number of verses traced it can be concluded that human rights are a concern for their substance to provide more comprehensive protection to children and women. The protection of children includes: protection of survival, getting adequate nutrition from birth to the appropriate time limit, getting fulfillment of the needs and rights of development of reason through education. Meanwhile protection for women in the form of; protection through marriage and stipulation of 'iddah when a husband's divorce and death occur, the right to hear complaints and difficulties is experienced and get equal rights in various joints of life as servants of God.
\end{abstract}

Keywords: Human rights, protection, children, women, ayat al-ahkam

\begin{abstract}
Abstrak
Tulisan ini bermaksud menjelaskan kedudukan hak asasi manusia dalam kaitannya dengan perlindungan anak dan perempuan dalam al-Qur'an. Berangkat dari kenyataan bahwa penggebirian hak-hak terhadap anak dan perempuan dalam lintas sejarah, penulis bermaksud untuk mengkaji nilai-nilai hukum normatifyang disarikan dari kitab suci al-Qur'an sebagai waf of life guna mendorong setiap individu menghormati hak-hak mereka. Penelitian ini dilakukan dengan studi dokumentasi sebagai teknis analisis pengumpulan datanya dan dianalisis dengan semi-tematik dari ayat-ayat al-Ahkam. Dari sejumlah ayat yang ditelusuri dapat disimpulkan bahwa hak asasi menjadi concern substansinya guna memberikan perlindungan yang lebih komprehensif kepada anak dan kaum perempuan. Adapun perlindungan kepada anak di antaranya berupa: perlindungan keberlangsungan hidup, mendapatkan asupan gizi yang cukup dari sejak lahir hingga batas waktu yang layak, mendapatkan pemenuhan kebutuhan dan hak pengembangan akal melalui pendidikan. Sementera perlindungan kepada kaum perempuan
\end{abstract}


berupa; perlindungan melalui perkawinan dan penetapan 'iddah ketika terjadi perceraian dan kematian suami, hak didengar keluhan dan kesusahan yang dialami dan mendapatkan kesamaan hak dalam berbagai sendi kehidupan layaknya sebagai hamba Tuhan.

Kata Kunci: Hak asasi manusia, perlindungan, anak, perempuan, ayat al-ahkam

\section{Introduction}

Human rights, the protection of children and women become the hot discourse in the Koran lately. Human rights which have been naturally gained by men since they were born on the earth while child protection which is very important and susceptibly they are exploited with particular purposes either materialistically or non materialistically. Women, the fact shows that there are many of them who have become the object of men's commerce, who are formed by the background of proverty, style, etc. In all hand of fight, women continously try get appropriate position in all kind of life education, jobs, social, economy, etc.

The problem of child protection and the position of women have become fenomenal discourse and are always interesting to talk. Nuswantari conducted the research related to the implementation of law protection toward the women who become victims of domestic violence in Madiun is appropriate to law no. 23 in 2004. In his research, he said that the implementation of law protection toward the women who became the victims of home violence in Madiun isn't appropriate with the law no. 23 in 2004. The problem faced are: There are not technical guide lines of implementation for women who became the victims of home violence. Other legislation haven't reflected justice for women, law agencies are still gender refraction, the law culture of society are gender refraction and patriarchally. ${ }^{1}$

In responding to the above fenomena,

${ }^{1}$ Nuswantari, "Implementasi Perlindungan Hukum Terhadap Perempuan Korban Kekerasan dalam Rumah Tangga di Kota Madiun", Citizenship Jurnal Pancasila dan Kewarganegaraan 5, no. 2 (2017), 97. some researchers have recommended that the Ministery of Empowering Women and Child Protection immediately to make, the directions of implementary, related to the involvement of society as child protectors at home and regional goverment of NTB needs to provide and create safe and comfortable environment for children's creativity. ${ }^{2}$

Another research conducted by penny who says that goverment has given protection for children through law instrument and ratification of several regulation for children. However, the role of goverment in protection considered less effective, therefore, some institutions were external to protect children, that was The National Comission of Child Protection For Indonesia (KPAI). ${ }^{3}$

Another barrier in this context is the policy made by Indonesian goverment in protecting children is not fully implemented yet. There is one factor which has contributed to the quantity of the violence among the children, which is forgaotten, is the violence among the children. The action of this violence happened because there is agresivity in the children which appear because of some cases. One of them is daily life influence. That's why this study recommends parents to take part in supervising children's playing behaviour. Then, goverment is expected to make rules to regulate game center which can take time after school to make sure that violence among the children can be minimized effectively. ${ }^{4}$

\footnotetext{
${ }^{2}$ Penny Naluria Utami, "Pencegahan Kekerasan Terhadap Anak dalam Perspektif Hak Atas Rasa Aman di Nusa Tenggara Barat", Jurnal HAM 9, no. 1 (2018): 1-17.

${ }^{3}$ Teguh Kurniawan, "Peran Parlemen dalam Perlindungan Anak," Aspirasi 6, no. 1 (2015): 37.

${ }^{4}$ Satriawan, Alfiana, Hafizha Fasya, Ayu Friska Amelia, Andi
} 
Law protection repressively according to Satrio Agung Richardi is by applying article 66 law no. 35 in 2014 about child protection is carried out through socializing the legislation related to child protection who are exploited economically or sexually, observation, report and giving sanction and involving some companies, coorporation, community self supporting institution community in abolishing exploitation toward children economically or sexually while protection preventively is the country, goverment, regional geverment, community, family and parents, head of the country have the duty of and are fully responsible for the implementing of child protection. $^{5}$

In protecting women, home violence has become important issue in the last decades. According to the report of World Health Organization (WHO) between $40 \%$ up to $70 \%$ women in the world are dead because of violence in family. In Indonesia from year to year, the number of the victims of home violence has increased so that it caused the external aspect of the law no. 23 in $2004 .^{6}$

Some efforts have been made to empower women and children. By using qualitative approach, it is found out in this article that the performance of implementing P2TPA (The Integrated Service Center For Child and Women) has been effective in achieving it's purposes because the result of evaluation of output program that is the coverage access, service delivery and the suitability of program with needs which have been effective in it's implementation. However, the integrated service center for women and children (P2TPA RDU) has some weaknesses

\footnotetext{
Ahmad Yani, "Analisis Kebijakan Perlindungan Kekerasan Terhadap Anak di Kota Makassar", Jurnal Analisis dan Kebijakan Publik 3, 1 (2017): 37.

${ }^{5}$ Satrio Ageng Rihardi, "Perlindungan Hukum Terhadap HakHak Anak Perempuan Sebagai Korban Eksploitasi Seksual”, tidak dipublikasi, 61.

${ }^{6}$ Rafikah dan Rahmawati, "Peranan Pusat Pelayanan Terpadu Pemberdayaan Perempuan Dan Anak (P2TP2A) Dalam Menghapuskan Kekerasan Dalam Rumah Tangga (KDRT) di Kota Bukittinggi”, Islam Realitas 1, no.2: 173.
}

in socialization especially for women who are the victims of home violance in the district (in Gunung Kidul, Kulon Progo, Bantul and Sleman). P2TPA RDU still has the shortage of conselors of human resources as implementers of garde in handling the women victims of home violence. ${ }^{7}$ The role of empowering women in home economic is sufficiently significant. It is proven from their daily activities which enables to help their husband to meet family needs. For example: making a cake, tailoring, etc. ${ }^{8}$

Thus, the violation of human rights happen in all law subjects included women and children. They are susceptible to sexual harmness. ${ }^{9}$ As we know that women and children are weak creature and they need more attention. This is connected with our country which highly support the values of human rights which has the principles of equality before the law in the constitution in which the protection is carried out. In this ease the law protection toward the children and women, today the government has found out the solution of special punishment about sexual insulting toward the children by giving maximum punishment like death sentence or sentence for life even by giving additional punishment by castrating the criminal executors. ${ }^{10}$

One of the factors which build the awareness to respect the children's and women's rights can be built through understanding religion through its holy texts. The position of this research is the important things how Islam through holy texts in advocating children's and women's rights. So that

\footnotetext{
${ }^{7}$ Lalu Fadlurrahman, "Kinerja Implementasi Kebijakan Penanganan Perempuan Korban Kekerasan”, Jurnal Kebijakan \& Administrasi Publik 18, no. 2 (2014): 161.

${ }^{8}$ Ranny Rahmawati, Sukidin, Pudjo Suharso, "Pemberdayaan Perempuan Korban Kekerasan dalam Rumah Tangga (KDRT) oleh Dinas Pemberdayaan Perempuan, Perlindungan Anak Dan Keluarga Berencana (DP3AKB) Kabupaten Jember", Jurnal Pendidikan Ekonomi 12, no. 2 (2018): 162.

${ }^{9}$ Ani Purwanti, Marzel Oina, "Strategi Penyelesaian Tindak Kekerasan Seksual Terhadap Perempuan dan Anak Melalui RUU Kekerasan Seksual", Masalah-masalah Hukum 47, no. 2 (2018): 138.

${ }^{10}$ I Ketut Sasmita Adi Laksana, "Perlindungan Hukum Bagi Korban Kekerasan Seksual Terhadap Anak dan Perempuan", Kertha Wicaksana 4, no. 1 (2017).
} 
they have good position and appropriate rights in social and individual life. The researcher in this context tries to discuss tematically in presenting the understanding of al-Ahkam verses from alQur'ān so that community is able to see how actually motivation and suggestion of Islam to their rights are kept and implemented well.

\section{Human Rights, History and Their Concept}

When analyzed from historical perspective, the condition of women before Islam was very worrying. The women didn't have natural right, not treated as human beings, killed alive in the age of "Jahiliyyah so that Islam came to reenlighten the order of destructive life. Al-Qur'ān mentioned the form of "Jahiliyah Harshness" will be asked for responsibility in the judgement day as mentioned Q.S. al-Takwir/81: 8-9.

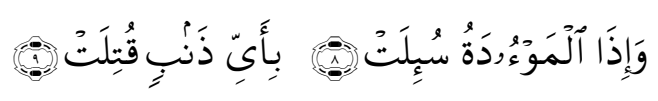

"When girls were burried (alive) was asked, what kinds of sinsituations they were killed."

The period of "Jahiliyah" is resistance againts the values of fundamental humanity, women's rights and arbitrarness toward the children's rights. Antithesis toward the condition of this depressing situation, Islam presents the concept of ballances (al-munawarah), honor (Ikhtiram), moeration (I'tidal) and protection (al-Mura'ah) for all individuals, without looking at gender, etnic, race and background of beliefs.

Human right is the right which has been owned since before one was born. Generally, human rights are valid universally. The principles of human rights are stated in the declaration of independence of USA and included in 1945 constitution of Republic of Indonesia. For example, paragraph 27 , paragraph 28 , paragraph 29 article 2 and paragraph 30 article no. $1 .{ }^{11}$

In paragraph 1 law no. 39 in 1999 about human rights mentioned that "human rights

\footnotetext{
${ }^{11}$ Id.m.wikipedia.org, accessed October 10, 2016.
}

is a set of rights which adhere on the essence, actually and the existence of human beings as god creatures who believe in one god and becomes his gift which must be respected, highly supported and protected by country, law and goverment, each individual for the sake of honor with the dignity protection and human values. ${ }^{12}$

The word "hak" itself comes from arabic "alHaq", the opposite of "al-bathil". ${ }^{13}$ In al-Qur'ān, the word "hak" when added by "al" becomes one name of Allah (al-Haq), also meant fight againts an evil, order which is done, justice, Islam, wealth, kingdom/something which is "Isabil" truth, death and strong willingness. ${ }^{14}$ The declaration of United Nation about human rights in the year 1948 gave definition about "hak" in detail and invited to leave out racism. Intrenational community to honor and to leave out racism (unsuriyyah). At that time, it was regarded as the peak effort of some countries to frame rights such as political, civil, economical, social and cultural right into special format ${ }^{15}$ which is valid for all individual of men, women and children.

Islam has declared human rights since 1400 years ago. The declaration which is very principal was conveyed by Prophet Muhammad in wada pilgrimage. Some of the substantive is as follows: human beings can't be differentiated among one and another based on gender, race and ethnic. They are equal infront of God, the difference is his or her devout. However, the reality in countries whose population are most moslems, some initiators of human rights are still confused with the existence of human rights. The indicator used is simple like authoritative leaders in the countries whose population are most moslem, the despising

\footnotetext{
${ }^{12} \mathrm{http} / /$ hukum.kompasiana.com/2011/12/28/hak-asasi-manusiadalam-islam-425478.Html, accessed on 12 October 2017.

${ }^{13}$ Ibn Manzur, Lisan al-'Arab, Jilid III (Kairo: Dar al-Hadits, 2003), 255.

${ }^{14}$ Yahya bin Muhammad Hasan Zamzami, Huquq al-Insan: Mafhumuh wa Tathbiqatuh fi al-Qur'ān (Mekkah: Jami'ah Um al-Qura', 1424 H), 7.

${ }^{15}$ Muhammad 'Ali Shalih al-Mansuri, al-Huquq al-Siyasah li al-Mar'at fi al-Syari'ah al-Islamiyyah wa al-Qanun al-Dawli (Beirut: al-Intisyar al-'Arabi, 2011), 12.
} 
of women rights and law which is againts human rights, in the frame of their understanding.

Wars in the area of gulf and Arabic countries also trigger the violating of human rights which are in evitable. This judgement as conveyed by Ann Elizabeth Mayer quoted by Lily Zakiyah Munir says that western cultures have become normative model toward the universality of international human rights. According to her, this kind of thing can't be avoided thinking upon that the whole concept of human rights was born in western countries while human rights can be adopted from several cultures of men included Islam. ${ }^{16}$ Allah said:

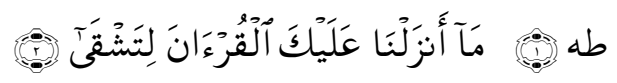

“Thaha, We don't reveal al-Qur'ān to you to make you troubled (Q.S. Thaha/20: 1-2).

The prophet Muhammad said:

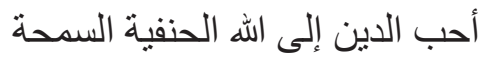

"The religion mostly loved by Allah is honest (al-hanafiyah) and tolerant (al-samhah)” (H.R. Bukhari). ${ }^{17}$

Moderatism (al-wasatiyyah) is the specific characteristic for moslem. The indication of moderatism is understood by Fatwa al-Khitab for part of Nas with the theme al-Shirat al-Mustaqim which brings people to the most magnificent and happiness in achieving wordly and the herelife. ${ }^{18}$

\section{Nash Syar'i About The Right of Living and To Keep Honor}

There are some basic rights in each individual where one live either he/she is faithful or not, live in the forest or in Sahara desert. These rights become basic recognization for each moslem. The

\footnotetext{
${ }^{16}$ Lily Zakiyah Munir, "Islam and Human Rights," makalah tidak diterbitkan, 1

${ }^{17}$ Imam al-Bukhari, Shahih al-Bukhari, kitab al-iman, bab al-din yusr.

${ }^{18} \mathrm{Abd}$ al-Rahman Hasan al-Maydani, al-Wasathiyyah fi al-Islam (Beirut: Mu'assasah al-Rayyan, 1416), 251.
}

rights meant: first, the right to live, this foundation of right mentioned in al-Qur'ān:

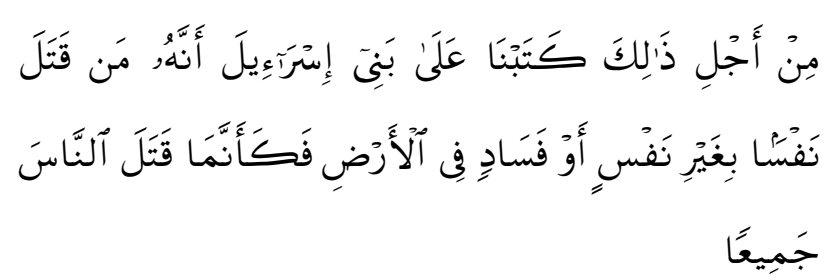

"Therefore, we determine (a decision) for Bani Israil, that who kills human being not because that man kills him or not to cause the damage on earth, so he kills all human beings" (Q.S. al-Maidah/5: 32).

In this verse, Allah mentioned specifically about Bani Israil because they belong to the ones who copiously cause the bloodshed of men. That's why, according to al-Qurthubi, Bani Israil belong to the first community decided about threat for those who kill men. ${ }^{19}$ The heavy consequency of killing man as a cruelty which impact badly in the life in the world and the day after. So that Allah compares like killing all men. This comparison as rad (startle) and tarhib (give the feeling of frightening) to the murder. The expert of law takes another side of meaning that Hostility toward individual is the same as having attitude toward community totally. The mentioning of "Yahudi" in this verse because of hasad among the dominant factor which come out among them to kill human being included the prophet. ${ }^{20}$

Killing an individual which is not justified by syara (common law) makes someone put into hell as punishment for those who kill all men. AlHasan and Ibnu Zayd say that requiring qishas as for its murderer the same as he/she kills all of human beings. ${ }^{21}$

\footnotetext{
${ }^{19}$ Muhammad bin Abi Bakr bin Farh al-Ansari al-Khazarji Syams al-Din al-Qurthubi, al-Jami li Ahkam al-Qur'ān, Juz VI (Kairo: Dar al-Kutub al-Misriyyah, 1964), 146.

${ }^{20}$ Majma' al-Buhuts al-Islamiyyah bi al-Azhar, Tafsir al-Wasith li al-Qur'ān al-Karim, Juz II (Kairo: al-Hay'ah al-'Ammah li al-Syu'un al-Amiriyyah, 1993), 1056.

${ }^{21} \mathrm{Abu}$ Hasan 'Ali bin Ahmad bin Muhammad bin 'Ali al-Wahidi, Tafsir al-Basith, juz VII (Saudi Arabia: 'Imadah al-Bahts al'Ilmi, 1430 H), 348.
} 
The right of living given by Islam to man occupies extraordinary position. An individual may not try to kill another. This action is considered criminal (jarimah) and the rule of qishas will be implemented as a response to the violence of human right. Allah clarifies:

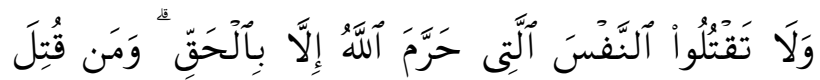

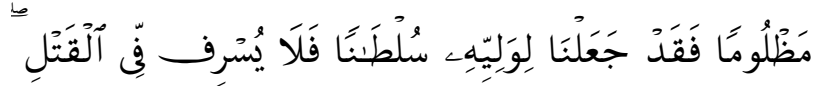

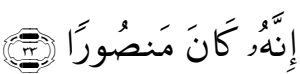

"and don't kill someone who is prohibited by Allah but with the right reason and who is killed cruelly, really we have given authority to the weirs (to take the revenge). On the other hand, the weirs are forhibidden to take the revenge cruelly. Actually, he/she is a person who gets help (Q.S. al-Isra'/17: 33).

Secondly, the right who get safety and life safety. This is directly clarified by al-Qur'ān after mentioning the right to live.

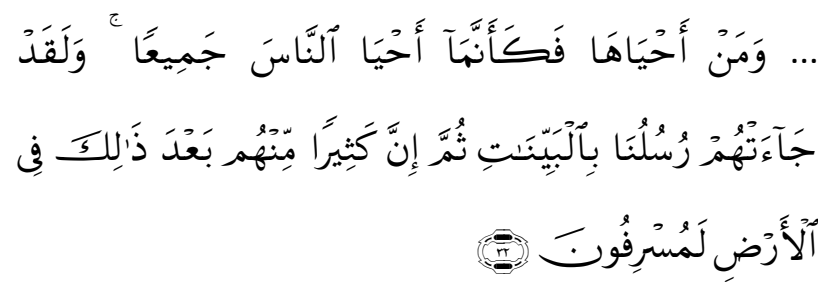

"...And who keep the life of human being, so he really keep all of human being and actually our messenger sent by God have come to bring clrear clarification, then, many of them have really oversteped the border in making the damage on the earth" (Q.S. al-Ma'idah/5:32).

Some of the commentators understand the second piece of this verse that all factors which make other people can live like the benefit, to prevent the murder, to help other which cause the death such as to save a person who has been sunk, fire and other things which include in this category. ${ }^{22}$ Some other thing also become a part of life safety. In case someone is sick or injured, others should give medical and if someone is suffering from hunger, others have to give them food. Al-Qur'ān places this as duty toward one another to save the whole life of human beings. ${ }^{23}$

Thirdly, to keep women's honor.

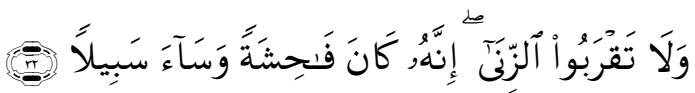

“And don't approach any sexual act outside of marriage. Any sexual act outside of marriage is a contemptible act and a bad way" (Q.S. al-Isra'/17: 32).

To keep women's honor and right Islam prohibit (someone) to approach the thing which can drive any sexual act outside of marriage, moreover, to do it, Fahisyah is a bad act and criminally seen. ${ }^{24}$ Al-Sabuni explain that the understanding not to approach any sexual act outside of marriage is a kind of optimal prohibition because this is a kind of preface of any sexual act outside of marriage like kissing, touching, glancing, etc. ${ }^{25}$ To close this strongly forbidden before lead to an activity of sexual act without marriage.

Fourth, the right to get the basic needs in life. Talking about economy, Allah describes in al-Qur'ān as follow:

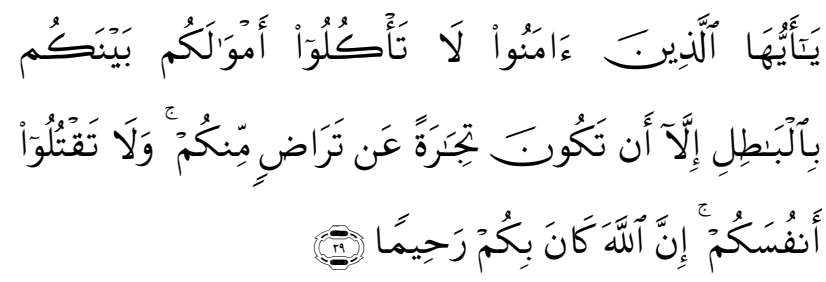

"Hey, the faithful, don't take one another's wealth invalid except by the way of valid

\footnotetext{
${ }^{22}$ Abu al-'Abbas Ahmad bin Muhammad bin Mahdi bin 'Ujaybah al-Hasani al-Anjazi al-Fasi al-Sufi, al-Bahr al-Majid, jilid II (Beirut: Dar al-Kutub al-'Ilmiyyah, 2002), 237.

${ }^{23} \mathrm{Abu}$ A'la al-Mawdudi, Human Rights in Islam (London: Islamic Foundation, 1980), 19.

${ }^{24}$ Majma' al-Buhuts, Tafsir al-Wasith..., juz V, 752.

${ }^{25}$ Muhamad 'Ali al-Sabuni, Safwat al-Tafasir, Jilid II (Kairo:

Dar al-Sabuni, 1997), 146.
} 
trade, you like one another. Don't kill yourself actually Allah loves you very much" (Q.S. an-Nisa/4: 29).

Eating invalidly has 2 meanings: first, eat or take someone else's wealth cruelly like carrying away, betrayal and thief. Secondly, by a game funding wealth which is every individual prohibited by syara like gambling and etc. ${ }^{26}$ This verse requires the faithful not to take or to own other people's property because this is a kind of violence to his/her brothers/sisters. ${ }^{27}$ From the explanation above, it is such clearly how Islam really concerns with others right related to property. By these principles, hopefully every individual can obey it so that no one who treat another cruelly or no one who is treated cruelly.

According to al-Jassas the prohibition to take someone else's property illegally is tied with the characteristic called al-bathil. All agreements which deal with damage, for example, the broken thing, the probidden thing to use like dog and pigs, the things which have no values according to syariah from the prohibited works in Islam included facid perfect trade which doesn't fulfill the requirement. All of the transaction like this categorized into al-bathil. ${ }^{28}$

Next, Islam give solution with the requirement in which there is the willingness in trade. AlSyafei says that the rule of trade is netral. The two sides have a certain attitude with taradhin (willing each other). Some of the commentators say that trade with taradhin is permitted with addition except trade transaction which is prohibided. The Prophet Muhammad sees this like gold and silver with transaction yadan bi yadin (directly), food and drinks is not allowed to have barter transaction with its type except with the same

\footnotetext{
${ }^{26}$ al-Wahidi, Tafsir al-Basith, juz III, 613.

${ }^{27} \mathrm{Abu}$ al-Hasan Muqatil bin Sulayman bin Basyir al-Azdari alBalkhi, Tafsir Muqatil Ibnu Sulayman, jilid I (Beirut: Dar Ihya al-Turath, $1423 \mathrm{H}), 368$.

${ }^{28} \mathrm{Ahmad}$ bin 'Ali Abu Bakr al-Razi al-Jassas al-Hanafi, Ahkam al-Qur'ān (Beirut: Dar Ihya al-Turath al-'Arabi, Jilid III, $(1405 \mathrm{H}), 128$.
}

amount either with dosage or weight. ${ }^{29}$

Five, the right of individual freedom. ${ }^{30}$ Individual freedoom means the space of movement to him or her to achieve his dream and his/her wish without any barriers from any party.

\section{Human Rights and Freedom In Belief}

The freedom meant here may not be rid of moral control and the belief convinced.

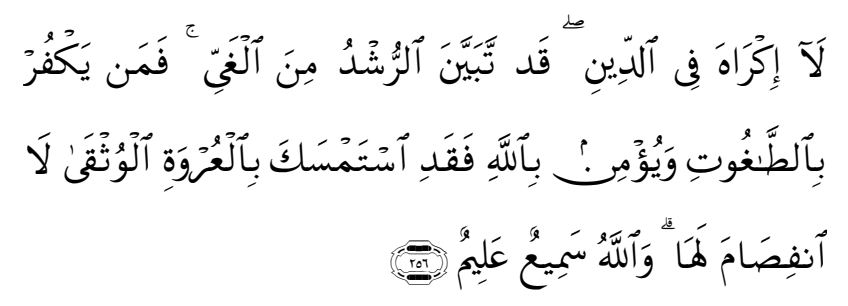

"No compulsion to follow Islam. Actually it is clear that which way is right which way is wrong. Who are disobeydent to "taghut" and faithful to Allah, so infact he or she really hold on to the knot of strong string which will not be broken, Allah greatly hear and know" (Q.S. al-Baqarah/2: 256).

The position of this verse after the verse which clarifies about the main pillars of religion is verses in al-Qur'ān that explain the power of Allah, the explanation of beliefs, the beliefs, the character of Allah and how the relation between the Creator and His creature. Next, it explains a right given to a smart person to choose the right religion without any doubt. When the verse that explain the power of Allah become mainly chastity of Allah, so this verse becomes freedom of men from all forms of pressing slavery and an obedient to other than Allah.

Before the verse explaining the power of Allah it has been explained the variation of religious community, if Allah wishes, he will force them in one religion. Then Allah explains about religion with the right unity of God. The truth is clear, a servant is given a choice and there is no

\footnotetext{
${ }^{29}$ al-Syafi'i, Tafsir al-Imam al-Syafi'i, jilid I (Saudi Arabia: Dar al-Tadmiriyyah, 2006), 429.

${ }^{30} \mathrm{Abu}$ A'la al-Mawdudi, Human Rights in Islam, 19.
} 
compulsion in it. ${ }^{31}$

This verse also becomes explanation to his commandement.

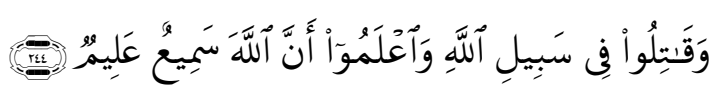

"Fight all of you in the way of Allah know that Allah most hear and know" (Q.S. alBaqarah/2: 244).

The hearer as if understand that wars to force enemies to enter Islam. This verse explains that there is no force to follow Islam. ${ }^{32}$ When seen from sabab al-nuzul, this verse related to a man from Anshor or those who have children then invited to follow Jewish or Christian. When Islam comes, they want to force them to follow Islam, Allah forhibit them for this and but let them follow Islam willingly.

It was narrated from Humayd bin Mas'adah with Sanad from Amir, he said A woman lives without children. She made a promise if she had a child, she will let it alive together with the expert of holy book with their own religion. Next, Islam comes a number of the children of Anshor still have a religion of holy book expert. They say, "We let them have a religion of holy book expert because we see that their religion is better then ours. When Islam comes, we force them to follow Islam." Here comes this verse. The children used to live with holy book expert, they have a religion of Jewish and they keep staying in their village, then have a religion of Islam. ${ }^{33}$

According to Mujahid and Hasan, the verse is connected with the people of Anshar who milked their baby to Bani al-Nadhir. Muhammad bin Amir told from Mujahid, he said, "The people of Jewish from Bani al-Nadhir suckled a number of children from Awf. When the Prophet

\footnotetext{
${ }^{31}$ Al-Fadhl bin al-Hasan al-Thabrasi, Majma' al-Bayan fi Tafsir al-Qur'ān (Beirut: Dar al-Fikr, 1957), 306.

${ }^{32}$ Muhammad al-Tahir bin 'Asyur, Tafsir al-Tahrir wa al-Tanwir, jilid III (Tunis: al-Dar al-Tunisiyyah li al-Nasyr, 1984), 25 (Next is called Ibnu 'Asyur).

${ }^{33}$ Muhammad bin Jarir al-Thabari, Tafsir al-Thabari, jilid V, 408-409
}

Muhammad ordered to expel them, those children said that they would go with them and followtheir religion. The family prohibited their children to follow the religion of the book expert and forced them to become moslem, then revealed this article.

According to at-Suddi and Masrug, this verse was revealed to an Anshar from Bani Awf. Ibnu Humayd narrated from Ibnu Abbas, he said: this verse revealed to a Anshor man from Bani Salim bin Awf, named al-Hushayn. He had 2 children followed the religion of Christian while he, himself, was a moslem. He said to the Prophet Muhammad, "Do I force both of these children because they didn't want to followIslam except Christian, Allah revealed this verse. ${ }^{34}$

When this verse is analyzed deeply, it can be started with understanding of etimology from the key word in that verse. Al-Ikra linguistically means requiring a person to do an action while the concerned can't understand the component of good deed in it, forced an activity which is not liked by them or burden something which is hated. This can also be done by intimidating (frighten) in order someone wants to do it. ${ }^{35}$ The compulsion is not only limited on the materialistical thing but it can be spiritual through political, social or economical pressure or others.

Al-Din means reward, the extent of meaning which is used is what can be the beliefand applied. This can be meaning wished. When this verse is revealed in the form of al-Khabar al-Munfi, appear the various of the understanding of exegesis expert toward the consequency the rule of its imposition of duty.

When this is analyzed more deeply, this verse can be concluded that the rule of religion, the activing of the compulsion in following a religion and having conviction although it not in the form

\footnotetext{
${ }^{34} \mathrm{Abu}$ Barakat 'Abdullah bin Ahmad al-Nasafi, al-Tafsir, jilid I (Beirut: Dar al-Kutub al-Lubnani, t.th), 129.

${ }^{35} \mathrm{Abu}$ Sa'id 'Abdullah bin 'Umar al-Baydhawi, Anwar al-Tanzil wa Asrar al-Ta'wil, jilid I (Mesir: al-Bahiyyah al-Misriyyah, 1925), 56.
} 
of sighat insya'iyyah. This understanding is confirmed with following verse (Qad tabayyana al-rusyd min al-ghay). The prohibition here started on hakikat takwinyyah that is the compulsion only in the period of physical action, "badani" not itiqad qalbi. Many commentators who explain who explain that the rule contained in this article, that is ikhbar bi ma'na al-nahy, the statement meaning prohibition.

In accordance with what is said by Asyur that the deny of force of the statement meaning prohibition. That is the deny of all reasons which causes the force in Islamic Law. This means, don't force someone to become moslem, La nafy $\mathrm{Li}$ al-jins, means that there may not be a force in all kinds of form, because the problem of faith must be based istidlal (the proof must be supported by argumentation) and the pleasure in thought and choice. ${ }^{36}$

There is sentence after it as a reason why forcing is forbidden. The forcing is only valid for important thing, there is no way to give explanation because the width of the understanding order or the lack of reaching mukallaf for that. There is a case which maybe explained in the bad and good aspects and the reply of explanation for those who left it so that there is no need for forcing. Even men can choose by themselves to do it or not an action to choose the consequency of punishment from their occupation.

Religion is a clear essence and the direction to follow is clear and digression to be left. There is no forcing in having a religion. ${ }^{37}$

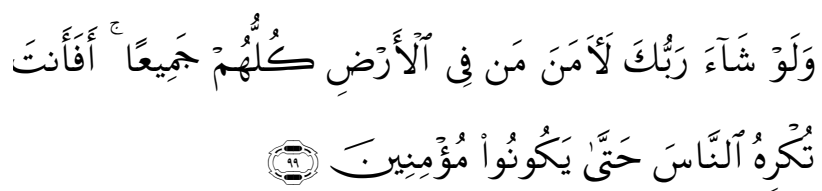

"And in case your lord wishes, certainly all people are faithful, all on the earth. Do you force human being? In order all of them to be

\footnotetext{
${ }^{36} \mathrm{Ibnu}$ 'Asyur, Tafsir al-Tahrir wa al-Tanwir, 26.

37، Abd al-Rahman bin Nasir al-Sa'di, Taysir al-Karim al-Rahman fi Tafsir Kalam al-Mannan, jilid I (Riyadh: al-Muassasah alSa'diyyah, t.th), 316.
}

faithful?"'(Q.S. Yunus/10: 99).

The right to respect other people's belief has been caltivated in a person who is faithful because we may not force their own belief. Logical consequency is we must acknowledge there are differences among people who have religions. A faithful person believes that every man will be responsible for what he/she believes and carry it out in life in this world.

The command which may not heap on curses other people's beliefs, mentioned in al-Qur'ān.

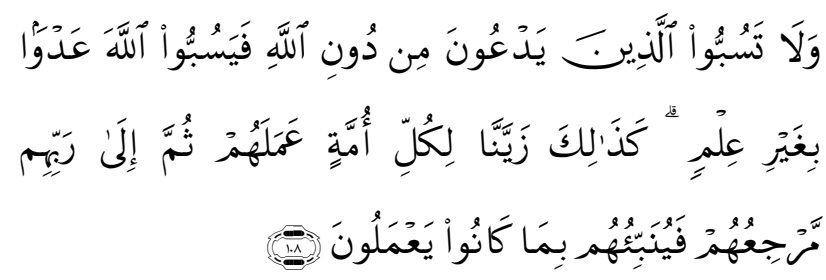

"And don't abuse object or other people's worship other than Allah because they will abuse Allah excessively without knowledge. Thus, we make everyone consider their work good. Then to the lord they revert to, He let them know what they did formerly" (Q.S. alAn'am/6: 108).

The above article indicates ethical religious proselytizing in Islam to the people who are polytheist. Although in moslem view, it is not right, we may not interact badly with them like considering and curse their worship. For nonmoslem, they respect and think holy in their beliefs. ${ }^{38}$

Related to about verse, Qatadah said that, moslem abuse verbally the objects worshiped by infidel, then they curse back. So Allah prohibits moslem to provoke to say something about Allah because of their ignorance, ${ }^{39}$ while other individuals may not curse, hate snap at, and underestimate them. Treat other people as the

\footnotetext{
${ }^{38}$ Muhammad al-Makki al-Nasiri, al-Tafsir fi Ahadits al-Tafsir, jilid, II (Beirut: Dar al-Gharb al-Islami, 1985), 150.

${ }^{39}$ al-Wahidi, al-Wasith fi Tafsir al-Qur'ān al-Majid, jilid, II (Beirut: Dar al-Kutub al-'Ilmiyyah, 1994), 310.
} 
creature of Allah become human rights for every individual.

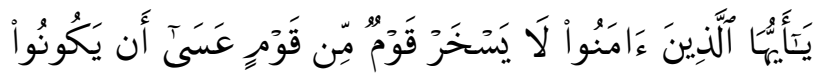

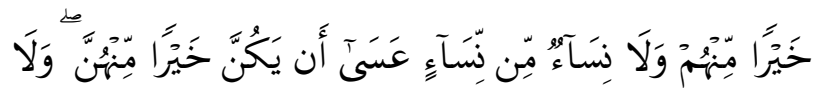

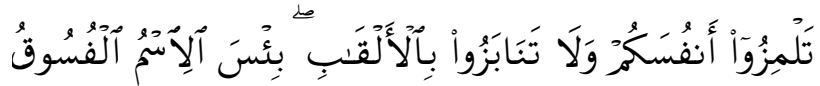

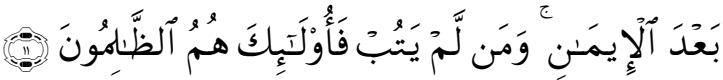

"Hey, the faithfull people, don't mock at other community, perhaps those who are mocked better than those who mock at and the group of women must not mock at other women because the women who are mocked are possibly better than those who mock at, and don't disapprove of yourself and don't name others with the bad name. the worst call is bad after being faithful and those who don't repent, they are actually cruel" (Q.S. al-Hujurat/49: 11).

There are some opinions about Sabab al-Nuzul of this verse, one of this verse revealed related to a group of Bani Tamim which who besmisched friends who are poor like Ammar Khabab, Ibnu Fahira, Bilal, Suhayb, Salman al-Farisi, Salim Abu Huraifah's slave and others when they are in difficult condition. This verse was revealed in order not to be included in insulting other people. This verse is also related to Ikrimah bin Abu Jahal when he came to Madinah as a moslem when he was seen moslems said "That is the son of Fir' aun of this community". He complained about this to the Prophet Muhammad, then this verse was revealed..$^{40}$

This verse also talk about the women who may not insult other women, the commentator connected with the presence of Aisyah RA's comment to Ummu Salamah that she was beautiful if she wasn't short. This is not permitted in Islam and then has general meaning either for men or women. ${ }^{41}$

\footnotetext{
${ }^{40}$ Majma' al-Buhuts, Tafsir al-Wasith..., jilid IX, 1042.

${ }^{41} \mathrm{Abu}$ al-Laits Nasr bin Muhammad bin Ibrahim al-Samarqandy
}

Ikhtitam confirmed there is equality among human beings in order they respect one another. The sign of "Insaniyyah" (humanity) with variation of types, color and religion. Therefore, moslem must interact and "ta'aruf" with other people and work cooperatively in supporting goodness of human beings universally. ${ }^{42}$

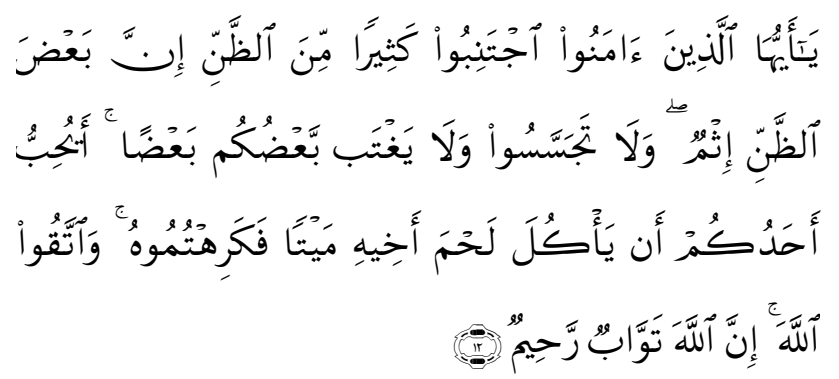

"Hey the faithful, keep away from prejudice, actually a part of prejudice is a sin and don't you gossip with other people's fault. Does one of you like to eat the meat of your brother who had died. Of course, you feel repugnant with his/her and please be pious to Allah. Infact, Allah greatly accept repant, the merciful" (Q.S. al-Hujurat/49: 12).

The above verse clarifies how to position other people. This verse forbids prejudiced badly at fellow because listening to the second party who don't wish badly from what is expressed or trapped in the condition in which he doesn't wish purposely. Dhann (bad prejudice) like this ordered to be avoided. No problem, it can't be expressed what is prejudiced. ${ }^{43}$ When expressing it, it will destroy for the rights of other people who are not sinful.

In the concept of al-Qur'ān, every individual has to feel a part of complexity from several perspective. Ananiyah (egolistic) must be paint and buried and thinking that human beings are bound one another, need to work together. The

al-Faqih al-Hanafi, Bahr al- 'Ulum, jilid III (Beirut: Dar al-Fikr, t.t.), 311.

${ }^{42}$ Muhammad al-Makki al-Nasiri, al-Tafsir fi Ahadits al-Tafsir, jilid VI, 65.

${ }^{43}$ al-Wahidi, Tafsir al-Basith, jilid XX, 359. 
intensity of man not only because of social intensity but also social integency in building life. The more intelligent he build the easier he achieves his dream in his life.

The right to be appreciated and respected becomes human right the individual has the reciprocal relation must be reflected in human life. The foundation can be found in al-Qur'ān.

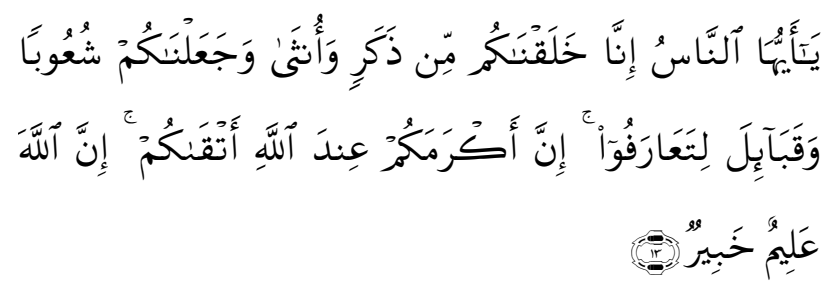

"Hey man, actually we create you from a man and a woman and create you to become nation and be ethnic groups in order you know one another. Actually, the most noble man among you beside Allah is a person who is the most noble man among you beside Allah is a person who is the most faithfull. Infact, Allah who know most and be most known with" (Q.S. al-Hujarat/49: 13).

Togetherness, keeping and appreciating human rights, I wonder it becomes coordinating constitution on fulfilling the human needs either materialistization or spiritual in accordance with the concept Maqashid al-Syariah. Human needs are categoriced into 3 types: dharuri, haji and tahsini. Human rights belong to dharuri (primer) in al-ghazali's terms are called al-dharuriyyat al-khamsah: hifiz al-din (taking care of religion), nafs (soul), aql (mind), nasl (family) and al-mal (property).

\section{Child Protection in al-Ahkam}

Children are generation whose materialization and spiritual must be prepared as caliph in preserving this earth. Child protection is considered as the protection of human in the future. Islam is positioned on the position of dharuri because they will live indifferent periods culturally, socially, financially, etc. Some of the forms of protection are as follows:

\section{Protection of Life Persistence}

Life is a kind of human right for each individual included children. They have right to get appropriate way of living to carry out trusteeship which are placed a burdened by their creator. Therefore, this right may not be emasculated with any model and reason. This prohibition is mentioned by al-Qur'ān (Q.S. alAn'am/6: 151).

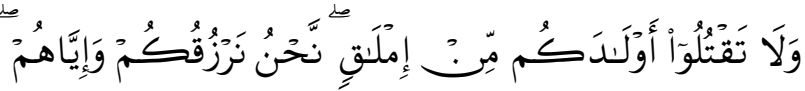 “... And don't kill your children because you are afraid to be poor. We give you lifelihood and them too..."}

The above verse is interpreted that killing children because of being frightened to be poor is forbidden by religion. ${ }^{44}$ The killing belongs to ten al-muharramat (forbidden action) Allah as mentioned in the above verse and next verse. Muhasabah (comfornity) of this verse with the previous one is tightly related where in the previous one Allah explains Muharramat al-mat'umat (the forbidden things related to the food) while in this verse it explained that muharramat maddiyyah wa ma'nawiyyah (the forbidden things either materialistic or non materialistic). ${ }^{45}$ The aspect reflected on the above verse how the attitude of men toward children who have just been born to get life guarantee from family, community and government which is based on the rule of constitution, the rule of Islam and customary law. ${ }^{46}$

The above verse can be understood life

\footnotetext{
${ }^{44}$ Jamal al-Din, Abu al-Farj 'Abd al-Rahman ibn 'Ali ibn Muhammad al-Jawzi, Zad al-Masir fi 'Ilm al-Tafsir, Jilid II (Beirut: Dar al-Kutub al-'Arabi, 1422), 91.

${ }^{45}$ Wahbah ibn Mustafa al-Zuhayli, al-Tafsir al-Munir fi al'Aqidah wa al-Syari 'ah wa al-Manhaj, Jillid VIII (Damaskus: Dar al-Fikr al-Mu a'sir, 1418), 93.

${ }^{46}$ Tedy Sudrajat, "Perlindungan Hukum Terhadap Hak Anak Sebagai Hak Asasi Manusia dalam Perspektif Sistem Hukum Keluarga di Indonesia”, Kanun Jurnal Ilmu Hukum XIII, no. 54 (2011): 111.
} 
persistence for every individual has to be watched and kept because it becomes fundament which is attached in each individual since a small child up to adult. The behaviour of killing children either directly after it was born or indirectly through abortion is on contrary to the principles of human rights which are attached in every individual.

\section{Protection with Sufficient Nutrient}

After birth a child has a right to get mother's milk indicating love, the pure of love as suitable nutrient for children. Mother's milk is the first protection for children's health, intelligence immune and all at once for emotional relationship.

Islam, a baby milked by his mother hawlayn kamilayn (two years at a stretch) for those who want to complete nest. The commandement of Allah in Q.S. al-Baqarah/2: 233:

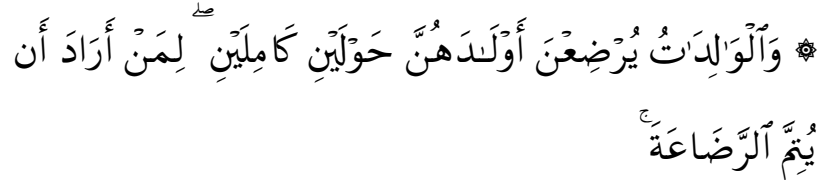

"And mother sucked her baby as long as 2 years for those who want to complete the nest...."

Two years is a suggested period as an option for those who want to complete the nest with benefits of materialistic and spiritual either connected with the mother or the baby itself. Liman arada anyutimun al-rada'ah regarded as takhfif (dispensation) and yusr (ease) ${ }^{47}$ Specially for a mother who has personal barrier.

\section{Protection of Adequate Needs}

A father has a responsibility to complete the need for food, clothing and board. The commandement of Allah in Q.S. al-Baqarah/2: 233.

\footnotetext{
${ }^{47} \mathrm{Abu}$ 'Abd Allah Muhamad ibn 'Abd Allah ibn 'Isa ibn Muhammad al-Mari al- Ilbiri, Tafsir al-'Aziz, Jilid I (Kairo: alFaruq al-Hadithah, 2002), 236.
}

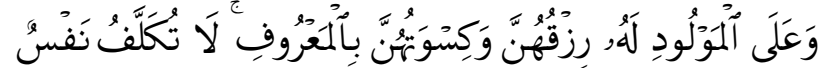

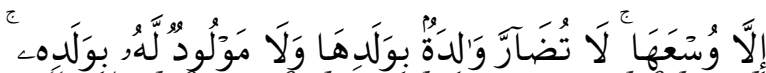
"....And for a father who prepare lifehood, clothing knownly and not burdened with someone except in accordance with his capacity. A mother is not burdened with her children. A father is not burdened with his children...."

Islam orders in order a child to get his/her needs but it does not burden his/her parents. Q.S. al-Thalaq/65: 7.

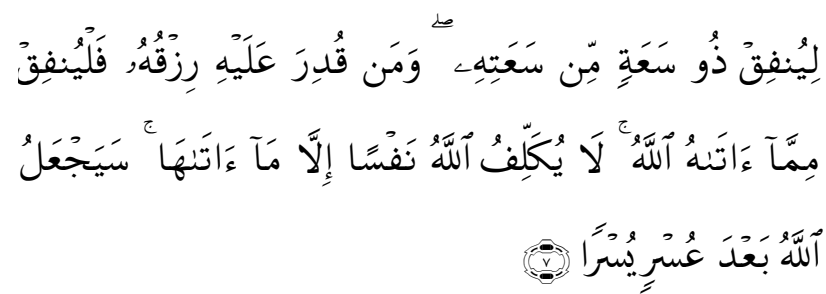

"Basic necessities of life should be given by those who are able to prepare in accordace with their capacities. For those who are not capable, he should give something what Allah gives him. Allah doesn't burden a person except who he gives him. Allah will make difficulty become ease".

This was passed by the Prophet Muhammad to Hindun:

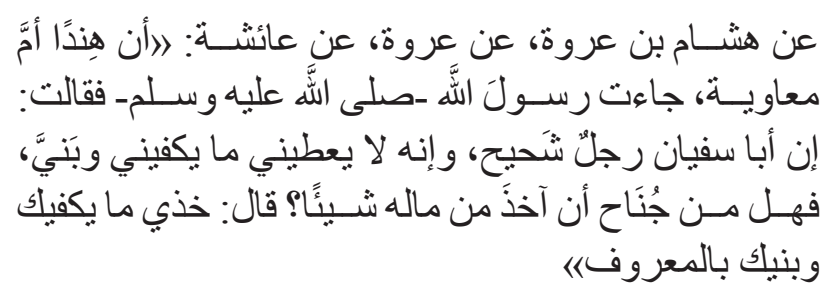

"From Hisyam Ibn Urwah, from Urwah, From Aisyah: actually Hindun, Mu'awiyah's mother met Prophet Muhammad, and then said. Actually Abu Sofyan, a miserly man. He didn't give or prepare my needs and my children's need. Am I sinful if I take some of his property? The Prophet Muhammad answered: Get some of his property which 
fulfil your needs and your children's needs", ${ }_{48}$

Children often become victim, besause of divorce, parent's death even the parent's activities to fulfil life needs so that the parents become labor in foreign countries. The lack of parents' attention gives bad impact to children's development, protectionand fulfilling children's rights. ${ }^{49}$

The above verse becomes a part of fulfilling children's rights like sufficiency of food, clothing and board. These verses don't only talk about the quantity of the meant fulfilling but also connected with capacity for heresy who carry out, in this case is parents. The ballance between duties and appropriateness is very important in carrying out the orders. Thus the religion empasizes how the intended rights run by minimum limit for its fulfilment.

\section{The Protection of Mind Through Education}

Some of the evidences Q.S. al-Isra/17: 70. The protection of mind through education mentioned in many verses in al-Qur'ān, among them:

Fisrt, an order to keep family from punishment, implicitly, al-Qur'ān command to a husband who guide and educate his family, for protection from the great disaster in Q.S. al-Tahrim/66: 6.

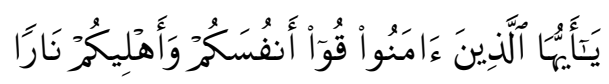

"Oh, the faithful, keep away youself and your family from the hell."

Second, ask your family to found praying. The commandement of Allah in Q.S. Thaha/20:132.

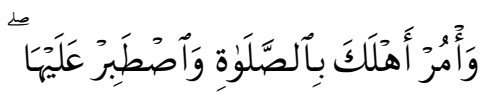

"Ask your family to perform the prayers and be patient for that."

\footnotetext{
48'Abd al-'Adhim ibn 'Abd al-Qawi al-Mundziri, Mukhtasar Sunan Abi Dawud, Jilid II (Riyadh: Maktabat al-Ma'arif, 2010), 495.

${ }^{49}$ Noer Indriati, Suyadi, Khrisnhoe Kartika, Sanyoto, dan Wismaningsih, "Perlindungan dan Pemenuhan Hak Anak: Studi Tentang Orangtua Sebagai Buruh Migran di Kabupaten Banyumas", Mimbar Hukum 29, no. 3 (2017): 475.
}

In hadith, Prophet Muhammad to convey to the husband to order his children to perform the prayers.

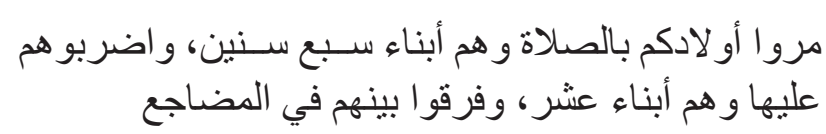

"Ask your children to perform the prayers when they are seven years old hit them when they are 10 years old when they don't perform the prayers and separate their beds".

Third, arrange the time and ask for permission to enter the parent's room. The commandement of Allah Q.S. al-Nur/24: 58.

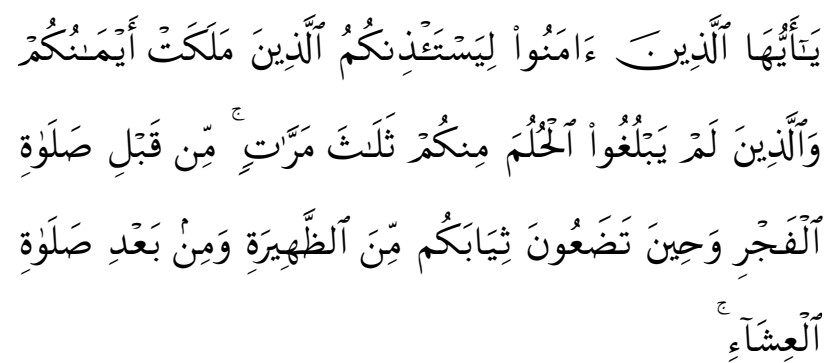

"Hey the faithful, ask you for permission for slave who are under your authority and the child who is not adult 3 times, before the prayer of "Subuh" when you take off your clothing when midday prayer and after evening prayer".

Child protection in this verse is in the form of instruction and their restriction in interacting with their parents at particular times before early morning prayer when the parents wear the sleeping clothes, when qailulah (afternoon sleep) and after evening prayer before going to bed..$^{50} \mathrm{At}$ these three prayer times, the parent parts of their bodies may be seen and this can give influence to child's psychology. The right of children toward parents or parent's responsibility toward children in fulfilling the children's needs, that is giving good names based on Islam's directions, give the education of moral values, either the

\footnotetext{
${ }^{50} \mathrm{Abu}$ al-Hasan 'Ali ibn Ahmad ibn Muhammad ibn 'Ali alWahidi, al-Wajiz fi Tafsir al-Kitab al-'Aziz, Jilid 1 (Damaskus: Dar al-Qalam, 1415 H), 769.
} 
ethnic to his lord or the education toward their lord (Allah). Ethical to one another, or ethical to their environment, developing cognitive, giving education of skill, giving nessecities of life and marrying his children. ${ }^{51}$

In the above verse, al-Qur'ān has determined that parents must concern to build good generation. The building then becomes children's right. When these are not done, it means they have ignored their duties which are entrusted to them. The parents neglectfulness will have bad consequencies toward future generation.

\section{Women Protection In The Verse Al-Ahkam}

The attention of al-Qur'ān toward women can be seen that so many themes used to show their category, like mar'ah, untsa, umm, walidah, zawj, halilah, sahibah, ukht and bint. The mentionary quanti, al-Qur'ān gives full attention to women, their protection, rights and duties with a number of positions they have, wives, mothers, friends, brothers and sisters, children, etc.

1. Women protection through iddah.

"Iddah" is waiting time or women's process of waiting after she is divorced from her husband either naturally because of death or intentionally like divorce, fasakh li'an and etc.

There is no interval in Jahilliah. They put forward their sexual desire and ignore women's rights. In this context, women at this time have no choice except to follow the tradition of fasid which is contaminated with moral decadence. Islam, on the other hand, give a perfect protection to women as in the interval time after divorce with the husband either because of death or divorce. al-Qur'ān mentions:

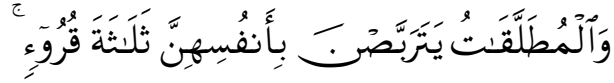

"The women who are divorced should restrain (waiting) three "teachers" (Q.S. alBaqarah/2: 228).

${ }^{51}$ Syahruddin Usman, "Hak Anak Terhadap Pendidkan," Auladuna 1, no. 2 (2014): 241.
In other verse Allah mentions:

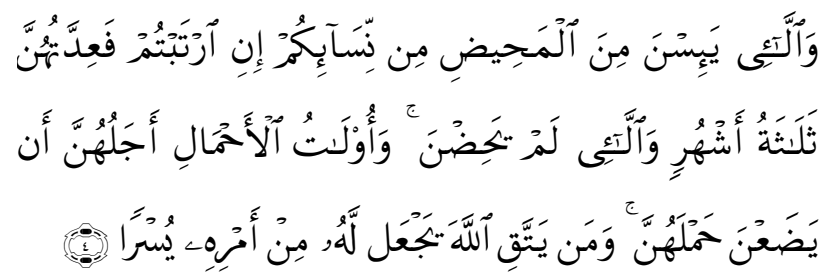

"The women who have stoped menstruation among your women if you are doubtful (about their iddah), the period of their iddah is three months and so do the women who have stopped menstruation and the pregnant women, the length of their iddah is until they give birth" (Q.S. al-Thalaq/65: 4).

The Pregnant women who are divorced by their husband, their iddah is until they give birth. ${ }^{52}$ When they are divorced "raj' $i$ " for those who menstruated so their waiting is 3 cleanses $^{53}$ and for those who stop menstruation so their waiting is until 3 months. ${ }^{54}$ When left by their husbands because of death, so their waiting is 4 months 10 days ${ }^{55}$ etc. the purpose of $i d d a h$ not only to know the cleanliness of the womb but it also means reconciliation and be in mourning where they must do them awarely. ${ }^{56}$

Iddah seen from its philosophy is more to the aspect of psychology. It's easy for women to forget the previsious experience. Iddah read as rest after one phase to another. This phase is a kind of respectation and appreciation to women in getting rights.

2. Women protection by accommodating their complaints.

The women's complaints are heard in Islam either in the context of family life or out of family. In family, women are given an opportunity to give input on the inconvenient life in natural borders.

\footnotetext{
${ }^{52}$ Q.S. al-Thalaq/65: 4 .

${ }^{53}$ Q.S. al-Baqarah/2: 228.

${ }^{54}$ Q.S. al-Thalaq/65: 4.

${ }^{55}$ Q.S. al-Baqarah/2: 234.

${ }^{56}$ Indar, :'Iddah dalam Keadilan Gender,' Jurnal Studi Gender \& Anak Yinyang 5, no.1 (2010): 127.
} 
This is meant in order that there are oppressing and oppressed (la dharar wa didhirar) in accordance with that, a number of duties must be carried out. The protection of balance (al-wazanah) among men and women. The case of Aus Ibn alShamat with his wife Khawlah bin Tha'lbah as an example which is explained in Q.S. Mujadalah. This woman complains because of her husband's behaviour toward Prophet Muhammad. She said, "O Messenger of Allah, our social intercourse has been long time, I have given a birth from him and he "dhihar" me. Prophet Muhammad said, "You are forbidden for him" she said that he complained about my difficulty to Allah. She repeated again until the revelation revealed. After that Prophet Muhammad ordered to call her husband then read Q.S. al-Mujadalah/58: 1-3.57

The writer thinks that a woman's complaint become her right to have expression. Islam appreciate them so that the complaints can be responded wisely. It means that women have the right to express their inspiration, aspiration and complain in family circle and community widely.

3. Women protection and the similarity of right.

Islam also pays attention in fairness (almusawat) in distribution of economy and property.

First, the protection of getting outcomes in accordance with everyone's efforts. The commandements of Allah in Q.S. al-Nisa'/4: 32.

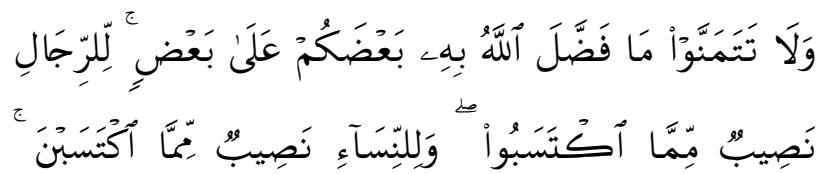

\footnotetext{
${ }^{57}$ Then she ordered her husband to pay "kafarat". Are able to liberate a servant? He answered, "No. Allah Says" (read Q.S. alNisa: 92). If he is not able to feed them, please fast 2 months at a stretch. He said, "Yes, Rasulullah if I am not able to feed them 3 times a day. I am worried if my eyes will have a trouble. Prophet Muhammad reads "al-mujadalah : 4". If you are not able to feed 60 of the poor. You are able to feel to feed 60 of the poor. He answered: no, Rasulullah, unless you help me. So the Messenger of Allah helped him and he gave food. Muhammad ibn Jarir ibn Yazid ibn Katsir ibn Ghalib al-Amili, Jami al-baya 'an Ta'wil Ayil Quran, Juz 22 (Beirut: Dar Hijrin, 2001), 446.
}

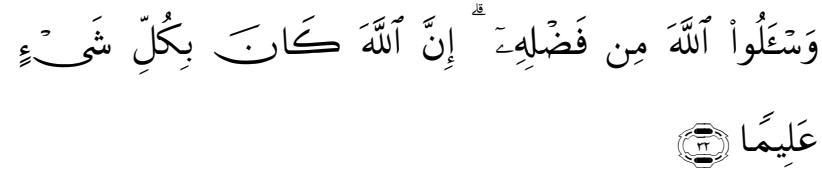

"you are forbidden to what Allah has given you more a part of gift for over another part. For men get a part of what they have done and for women get a part of what they have done. Actually Allah knows about everything."

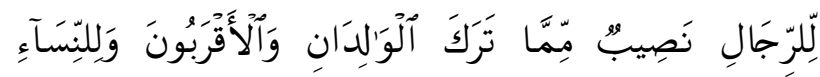

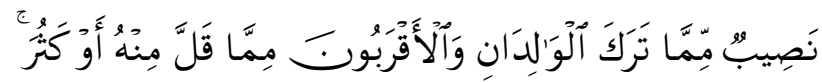

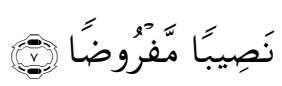

"A man has a part of what their parents have close family and women have the rights of what their parents left and the relatives either in the small number or many as a particular rule (Q.S. al-Nisa'/4: 7)."

This verse connected with Umi Salamah's expression. "Ya Rasulullah, if we were men, then we can fight so that we get reward like men have, then Allah revealed the above verse. ${ }^{58}$

Muamalah must be with al-ta'anni (the attention to an activity which must be done) not al-tamanni (fantasy). ${ }^{59}$ An individual work harder either a man or a woman he/she has a right to get the outcome in accordance with his/her activity. The commandement of Allah Q.S. al-Nahl/16: 97.

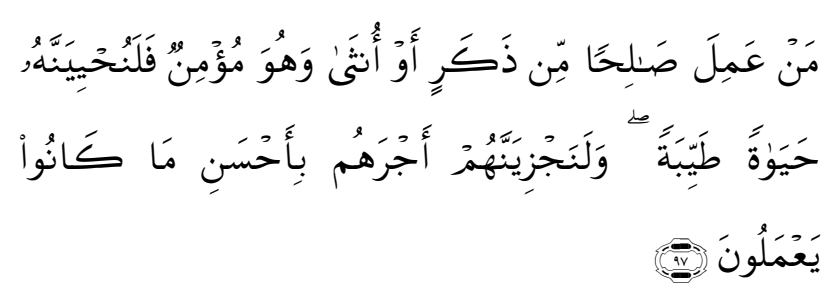

"whoever who does good deed either men or women we will give good life and the best

\footnotetext{
${ }^{58} \mathrm{Abu}$ al-Hasan 'Ali ibn Ahmad ibn Muhammad ibn 'Ali alWahidi, al-Wajiz fi Tafsir al-Kitab al- 'Aziz, Jilid 1 (Damaskus: Dar al-Qalam, 1415H), 261.

${ }^{59 ،}$ Abd al-Karim ibn Hawazin ibn 'Abd al-Malik al-Qusyairi, Lata'if al-Isyarat, Jilid 1 (Mesir: al-Hay'ah al-Misriyyah al'Ammah li al-Kitab, t.t), 328.
} 
response to what they have done."

The pronounciation man indicates the generalization of meaning covering anybody who does the meant activity. Al-hayat tayyibah intended in this verse means rightful livelihood. Ibn Abbas thinks that the meaning of al-kasb al-tayyib (good effort) and al-amal salih (good deed). ${ }^{60}$ The model of residents dialogue to develop the competence of community in handling the issue of human right of women and equivalency of men and women which they regard the most important. ${ }^{61}$

\section{Conclusion}

Human rights become the basic rights which has been recognized by Islam since the beginning. Islam gives attention to human beings since they were born. This confession must be understood by every individual. The same thing is connected with the protection for women and children. These two themes are connected with the tradition in Jahiliyyah where they didn't get the portion of appropriate protection in individual and social life. Islam comes to bring social reformation and the law of family to give the protection of fundamental protection and especially in this theme connected with children and women.

From a number of the verses of ahkam, there are many fundamental right mentioned to give comprehensive protection to children and women. There are some kind of protection for children such as the protection of life, persistence, the protection of sufficient nutrient, the protection of sufficient needs, the protection of mind through education while the protection for women can be: The protection of women through iddah, the protection by accommodating women's complains, the protection of women and the

\footnotetext{
${ }^{60} \mathrm{Abu}$ Muhammad 'Abd al-Rahman ibn Idirs ibn al-Munzir alTamimi, Tafsir al-Qur'ān al-'Azim li Ibn Abi Hatim, Jilid 7 (Saudi Arabia: Maktabah Nazzar Mustafa al-Baz, 1419 H), 2301. ${ }^{61}$ Anila Umriana, Moh. Fauzi dan Hasyim Hasanah, "Penguatan Hak Asasi Perempuan dan Kesetaraan Gender Melalui Dialog Warga," Sawwa 12, no. 1 (2016): 42.
}

aquality of right.

Fundamental rights which are attached on child and women protection are not only connected with material aspect but also psychological and emotional aspects. Psychological aspect to develop the potencies in such individual in order to develop in parallel with physical growth. Emotional aspect emphasize on the psychological stabilityin facing the problems of life. Fulfilling human rights for children and women will increase the spirit of living and commemorate prosperity of good living physically and spiritually.

\section{References}

al-Amili, Muhammad ibn Jarir ibn Yazid ibn Katsir ibn Ghalib. Jami al-bayan 'an Ta'wil Ayil Qur'ān. Beirut: Dar Hijrin, 2001.

al-Balkhi, Abu al-Hasan Muqatil bin Sulayman bin Basyir al-Azdari. Tafsir Muqatil Ibnu Sulayman. Beirut: Dar Ihya al-Turath, $1423 \mathrm{H}$.

al-Baydhawi, Abu Sa'id 'Abdullah bin 'Umar. Anwar al-Tanzil wa Asrar al-Ta'wil. Mesir: al-Bahiyyah al-Misriyyah, 1925.

Fadlurrahman, Lalu. "Kinerja Implementasi Kebijakan Penanganan Perempuan Korban Kekerasan”. Jurnal Kebijakan \& Administrasi Publik 18, no. 2 (2014): 161.

al-Hanafi, Abu al-Laits Nasr bin Muhammad bin Ibrahim al-Samarqandy al-Faqih. Bahr al- 'Ulum. Jilid III. Beirut: Dar al-Fikr, t.t.

Ibn 'Asyur, Muhammad al-Tahir. Tafsir alTahrir wa al-Tanwir. Tunis: al-Dar alTunisiyyah li al-Nasyr, 1984.

Ibn Manzur. Lisan al-'Arab. Kairo: Dar alHadits, 2003.

al-Ilbiri, Abu 'Abd Allah Muhamad ibn 'Abd Allah ibn 'Isa ibn Muhammad al-Mari. 
Tafsir al-'Aziz. Kairo: al-Faruq alHadithah, 2002.

Indar. 'Iddah dalam Keadilan Gender." Jurnal Studi Gender \& Anak Yinyang 5, no. 1 (2010): 127.

Indriati, Noer, Suyadi, Khrisnhoe Kartika, Sanyoto, dan Wismaningsih. "Perlindungan dan Pemenuhan Hak Anak: Studi Tentang Orangtua Sebagai Buruh Migran di Kabupaten Banyumas". Mimbar Hukum 29, no. 3 (2017): 475.

Jamal al-Din, Abu al-Farj 'Abd al-Rahman ibn 'Ali ibn Muhammad al-Jawzi. Zad al-Masir fi 'Ilm al-Tafsir. Beirut: Dar alKutub al-'Arabi, 1422.

al-Jassas, Ahmad bin 'Ali Abu Bakr al-Razi al-Hanafi. Ahkam al-Qur'ān. Jilid III. Beirut: Dar Ihya al-Turath al-'Arabi, 1405H.

Kurniawan, Teguh. "Peran Parlemen dalam Perlindungan Anak". Aspirasi 6, no. 1 (2015): 37.

Laksana, I Ketut Sasmita Adi. "Perlindungan Hukum Bagi Korban Kekerasan Seksual Terhadap Anak dan Perempuan". Kertha Wicaksana 4, no. (2017).

Majma' al-Buhuts al-Islamiyyah bi al-Azhar. Tafsir al-Wasith li al-Qur'ān al-Karim. Kairo: al-Hay'ah al-'Ammah li al-Syu'un al-Amiriyyah, 1993.

Mansuri, Muhammad 'Ali Shalih. al-Huquq al-Siyasah li al-Mar'at fi al-Syari'ah alIslamiyyah wa al-Qanun al-Dawli. Beirut: al-Intisyar al-'Arabi, 2011.

al-Maududi, Abu A'la. Human Rights in Islam. London: Islamic Foundation, 1980.

al-Maydani, 'Abd al-Rahman Hasan. alWasathiyyah fi al-Islam. Beirut: Mu'assasah al-Rayyan, 1416.

al-Mundziri, 'Abd al-'Adhim ibn 'Abd al-Qawi.
Mukhtasar Sunan Abi Dawud. Riyadh: Maktabat al-Ma'arif, 2010.

Munir, Lily Zakiyah. "Islam and Human Rights." Makalah tidak diterbitkan.

al-Nasafi, Abu Barakat 'Abdullah bin Ahmad. alTafsir. Beirut: Dar al-Kutub al-Lubnani, t.th.

al-Nasiri, Muhammad al-Makki. al-Tafsir $f i$ Ahadits al-Tafsir. Beirut: Dar al-Gharb al-Islami, 1985.

Nuswantari. "Implementasi Perlindungan Hukum Terhadap Perempuan Korban Kekerasan dalam Rumah Tangga di Kota Madiun". Citizenship Jurnal Pancasila dan Kewarganegaraan 5, no. 2 (2017): 97.

Purwanti, Ani dan Marzel Oina. "Strategi Penyelesaian Tindak Kekerasan Seksual Terhadap Perempuan dan Anak Melalui RUU Kekerasan Seksual". Masalahmasalah Hukum 47, no. 2 (2018): 138.

al-Qurthubi, Muhammad bin Abi Bakr bin Farh al-Ansari al-Khazarji Syams al-Din. alJami li Ahkam al-Qur'ān. Juz VI. Kairo: Dar al-Kutub al-Misriyyah, 1964.

al-Qusyairi, 'Abd al-Karim ibn Hawazin ibn 'Abd al-Malik. Lata'if al-Isyarat. Mesir: al-Hay'ah al-Misriyyah al-'Ammah li alKitab, t.t.

Rafikah dan Rahmawati. "Peranan Pusat Pelayanan Terpadu Pemberdayaan Perempuan dan Anak (P2TP2A) dalam Menghapuskan Kekerasan dalam Rumah Tangga (KDRT) di Kota Bukittinggi”. Islam Realitas 1, no.2: 173 .

Rahmawati, Ranny, Sukidin, Pudjo Suharso. "Pemberdayaan Perempuan Korban Kekerasan dalam Rumah Tangga (KDRT) oleh Dinas Pemberdayaan Perempuan, Perlindungan Anak Dan Keluarga Berencana (DP3AKB) Kabupaten 
Jember". Jurnal Pendidikan Ekonomi 12, no. 2 (2018): 162.

Rihardi, Satrio Ageng. "Perlindungan Hukum Terhadap Hak-hak Anak Perempuan Sebagai Korban Eksploitasi Seksual”. tidak dipublikasi, 61.

al-Sa'di, Abd al-Rahman bin Nasir. Taysir al-Karim al-Rahman fi Tafsir Kalam al-Mannan. Riyadh: al-Muassasah alSa'diyyah, t.t.

al-Sabuni, Muhamad 'Ali. Safwat al-Tafasir. Jilid II. Kairo: Dar al-Sabuni, 1997.

Satriawan, Alfiana, Hafizha Fasya, Ayu Friska Amelia, Andi Ahmad Yani. "Analisis Kebijakan Perlindungan Kekerasan terhadap Anak di Kota Makassar". Jurnal Analisis dan Kebijakan Publik 3, no. 1 (2017): 37.

Sudrajat, Tedy. "Perlindungan Hukum Terhadap Hak Anak Sebagai Hak Asasi Manusia dalam Perspektif Sistem Hukum Keluarga di Indonesia”. Kanun Jurnal Ilmu Hukum 13, no. 54 (2011): 111.

al-Sufi, Abu al-'Abbas Ahmad bin Muhammad bin Mahdi bin 'Ujaybah al-Hasani alAnjazi al-Fasi. al-Bahr al-Majid. Beirut: Dar al-Kutub al-'Ilmiyyah, 2002.

al-Syafi'i. Tafsir al-Imam al-Syafi'i. Saudi Arabia: Dar al-Tadmiriyyah.

al-Tamimi, Abu Muhammad 'Abd al-Rahman ibn Idirs ibn al-Munzir. Tafsir al-Qur'ān al-'Azim li Ibn Abi Hatim. Saudi Arabia: Maktabah Nazzar Mustafa al-Baz, 1419 H.

al-Thabrasi, Al-Fadhl bin al-Hasan. Majma' alBayan fi Tafsir al-Qur'ān. Beirut: Dar al-Fikr, 1957.

Umriana, Anila, Moh. Fauzi dan Hasyim Hasanah. "Penguatan Hak Asasi Perempuan dan Kesetaraan Gender Melalui Dialog Warga". Sawwa 12, no. 1 (2016): 42.

Utami, Penny Naluria. "Pencegahan Kekerasan Terhadap Anak dalam Perspektif Hak Atas Rasa Aman di Nusa Tenggara Barat”. Jurnal HAM 9, no. 1 (2018): 1.

al-Wahidi, Abu al-Hasan 'Ali ibn Ahmad ibn Muhammad ibn 'Ali. al-Wajizfi Tafsir alKitab al-'Aziz. Damaskus: Dar al-Qalam, $1415 \mathrm{H}$

-------. Tafsir al-Basith. Saudi Arabia: 'Imadah al-Bahts al-'Ilmi, $1430 \mathrm{H}$.

-------. al-Wasith fi Tafsir al-Qur'an al-Majid. Beirut: Dar al-Kutub al-'Ilmiyyah, 1994.

Zamzami, Yahya bin Muhammad Hasan. Huquq al-Insan: Mafhumuh wa Tathbiqatuh fialQur'an. Mekkah: Jami'ah Um al-Qura', $1424 \mathrm{H}$.

al-Zuhayli, Wahbah ibn Mustafa. al-Tafsir al-Munir fi al-'Aqidah wa al-Syari 'ah wa al-Manhaj. Damaskus: Dar al-Fikr al-Mua'sir, 1418. 